\title{
A TÁRSAS PRAGMATIKAI KOMMUNIKÁCIÓS ZAVAR: TERMINOLÓGIAI KÉRDÉSEK, TÜNETI DIAGNOSZTIKAI MÓDSZEREK ÉS PROBLÉMÁK
}

\author{
SVINDT VERONIKA ${ }^{1}$ \\ ${ }^{1}$ MTA Nyelvtudományi Intézet \\ E-mail: svindt.veronika@nytud.mta.hu
}

Beérkezett: 2018. november 14. - Elfogadva: 2019. április 2.

\begin{abstract}
A társas (pragmatikai) kommunikáció zavara az autizmus spektrum zavar és a specifikus nyelvi zavar határán álló fejlödési zavar. Vezetố tünete a nyelv kontextusban való inadekvát használata más kognitív képességek viszonylagos épsége mellett. Önálló kategóriaként a diagnosztikus és terápiás gyakorlatban való jelenléte meglehetösen friss (2013). A társas pragmatikai kommunikációs zavar (PKZ) mibenléte, pontos etiológiája, vizsgálhatósága, más fejlódési zavarokkal való kapcsolata, illetve azoktól való elkülöníthetôsége élénk vitákat generál a zavar körülbelül harminc évvel ezelôtti elsô leírása óta. A hazai fejlödéspszichológiai és gyógypedagógiai gyakorlatban jelenleg nincsen átfogó, széles körben alkalmazott eljárás ezen gyermekek célzott szúrésére, és maga a diagnosztikai kategória sem került be a köztudatba. Jelen tanulmány áttekintést kíván nyújtani a téma kutatástörténetéról, valamint a szürés és a differenciáldiagnosztika nehézségeiról és lehetôségeiról.
\end{abstract}

Kulcsszavak: társas kommunikáció zavara, szociális kommunikációs zavar, pragmatikai nyelvi zavar, autizmus spektrum zavar, specifikus nyelvi zavar 


\section{BEVEZETÉS}

Jelen tanulmány célja áttekintést nyújtani a DSM-5-ben (2013) bevezetett új diagnosztikai kategóriáról, a társas (pragmatikai) kommunikációs zavarról, amely mind a kutatásban, mind a gyógypedagógiai gyakorlatban meglehetôsen kevés figyelmet kap. Elsố leírása óta (Rapin és Allen, 1983) legfeljebb százas nagyságrendú kutatás született a témában (ezek összefoglalása: Swineford, Thurm, Baird, Wetherby és Swedo, 2014; Topal, Samurcu, Taskira, Tufan és Semerci, 2018), szemben a vele szoros kapcsolatban álló, és kiterjedt szakirodalommal rendelkezô autizmus spektrum zavarral (ASD), valamint az egyre nagyobb figyelmet kapó specifikus nyelvi zavarral (SNYZ). Hazánkban nem született még sem átfogó, sem e zavar specifikus természetét bemutató írás. ${ }^{1}$

\section{A pragmatikai képesség zavarai}

A gyógypedagógiai megközelítésú szakirodalomban a szociális/társas kommunikáció fogalma gyakran a pragmatikai nyelvhasználat szinonimájaként fordul elô. ${ }^{2}$ A gyógypedagógia és a nyelvtudomány pragmatikaértelmezései számos ponton különböznek egymástól, jelen tanulmánynak nem célja ezen eltérések bemutatása. A szociális kommunikáció a nyelv interszubjektív közegben való alkalmazása, amely a megfelelôen múködô pragmatikai kompetencia nélkül nem lehet hatékony. A pragmatikai képességek körébe tartozik az implicit jelentéstartalmak megértése (pl. preszuppozíciók, implikatúrák, beszédaktusok, metaforák vagy irónia), a társalgási és udvariassági aktusok használata, a beszédszituáció felmérése és az ahhoz való rugalmas alkalmazkodás, a diskurzus további szabályainak figyelembevétele és alkalmazása (pl. fordulóváltás, figyelemirányítás, témaválasztás és -váltás); a kontextusból származó következtetések levonására való képesség vagy éppen a kontextus verbális és nem verbális információinak felhasználása a produkció során.

A pragmatikai kompetencia kialakulása már jóval a strukturális nyelvi fejlôdés elôtt megkezdődik: a gyermekek hamarabb képesek szándékaik kifejezésére, minthogy az elsố szavaikat kimondanák (Bara, Bosco és Bucciarelli, 1999). Noha a fejlôdés korán kezdôdik, a pragmatikai képességek sokkal lassabban fejlôdnek, mint ahogyan a fonológia, morfológia, szintaxis vagy a szemantika megszilárdulnak (Cummings, 2014). A pragmatikai képességet ezért a strukturális nyelvi képességek stabil kialakulása után, körülbelül 4-5 éves kortól kezdve célszerú vizsgálni. A pragmatikai képesség zavara lehet elsôdleges vagy másodlagos probléma egy másik képességzavar vagy kognitív zavar tüneteként (pl. figyelemzavar, viselkedéses, szociális, érzelemszabályozási vagy éppen nyelvi problémák). Gyakori, hogy a viselkedéses problémák nyelvi vagy pragmatikai zavarral is együtt járnak, és fordítva: a pragmatikai vagy nyelvi zavarok következménye gyakran lehet inadekvát viselkedés. Helland, Lundervold, Heimann és Posserud

Köszönettel tartozom névtelen lektoraimnak a gondos és alapos véleményért, valamint a számos elốrevivô kritikai megjegyzésért. Köszönet illeti továbbá Lukács Szandra gyógypedagógust is a gyógypedagógiai gyakorlatot illetô kérdésekben nyújtott segítségért.

A gyógypedagógiai gyakorlatban e fejlódési zavarra a szociális kommunikációs funkciózavar elnevezés jelenik meg leggyakrabban. 
(2014) szerint figyelemhiányos hiperaktivitás-zavarral (ADHD) élô gyermekeknél 82,1\%-ban figyelhetô meg nyelvi és/vagy pragmatikai zavar is, Asperger-szindrómásoknál pedig $90,5 \%$ ez az arány.

A pragmatikai nehézségekkel is együtt járó zavarok hátterében fejlôdési, neurobiológiai, genetikai, mentális vagy szerzett zavarok is állhatnak, amelyek nemritkán egymással is átfedést mutathatnak. A fejlődési zavarok között pragmatikai nehézségek jelentkezhetnek tehát autizmus spektrum zavarban; specifikus nyelvi zavarban; ADHD-ban; viselkedési és érzelemszabályozási zavarokban; valamint bizonyos genetikai hátterú zavarokban, úgymint Williams-szindrómában; Down-szindrómában; vagy fragilis X-szindrómában. Emellett az intellektuális képességzavarok önmagukban is járhatnak együtt pragmatikai problémákkal. A szerzett zavarok közül a jobb agyfélteke sérüléseinek következménye is lehet részleges vagy teljes pragmatikai zavar. Bizonyos neurodegeneratív betegségekben (pl. Alzheimer-kór, demencia) a betegség elórehaladottságának függvényében szintén fennállhat kisebb-nagyobb mértékú, a pragmatikai nyelvhasználatot érintô zavar. A mentális zavarok közül a skizofréniában figyeltek meg érzékelhetô pragmatikai problémákat.

A pragmatikai nyelvi zavar, a szociális kommunikáció zavara vagy a pragmatikai képességek zavara megnevezés tehát meglehetôsen sokféle problémát takarhat. Jelen tanulmányban a fejlôdési zavarok közé sorolható primer pragmatikai korlátozottságot mutató, önálló diagnosztikai kategóriaként létezô társas (pragmatikai) kommunikációs zavart (PKZ) mutatjuk be.

\section{A társas (pragmatikai) kommunikációs zavar felfedezésének története}

A kurrens elméletek a társas (pragmatikai) kommunikáció zavarát az autizmus spektrum zavar és a specifikus nyelvi zavar határterületein álló jelenségnek tartják, elsó leírása 1983-ból származik (Rapin és Allen, 1983). Az alábbiakban röviden áttekintjük azt az utat, amely végül az önálló diagnosztikai kategória megszületéséhez vezetett. A határterületen álló gyermekek azonosítását az autizmus spektrum zavar és a specifikus nyelvi zavar diagnosztikájának fejlôdése, a pontosabb mérôeljárások, a növekvô tudás és lehetôségek tették lehetôvé (magyar nyelven ld. pl. Csepregi és Stefanik, 2012; Gyôri, 2014; Lukács, Kas és Pléh, 2014).

A pragmatikai nyelvi zavar leírásában Rapin és Allen (1983) két típust különböztetett meg: az autizmus nélkül fennálló szemantikai-pragmatikai szindrómát (semantic-pragmatic syndrome without autism), valamint a szintaktikai-pragmatikai szindrómát (syntactic-pragmatic syndrome). Néhány évvel késôbb a szemantikai-pragmatikai zavar terminus terjedt el (semantic pragmatic disorder, Bishop és Rosenbloom, 1987). Botting és Conti-Ramsden (1999) munkájukban a pragmatikai nyelvi zavar (pragmatic language impairment) fogalmat tartják megfelelónek.

Már az 1980-as években felmerült, hogy ezek a gyermekek az autizmus spektrum zavar és a specifikus nyelvi zavar határterületein helyezkednek el, egyik vagy másik kategóriába való sorolásuk azóta is élénk vita tárgya, mivel viselkedéses és nyelvi jellemzôik alapján egyik kategória kritériumait sem merítik ki teljeskörúen (vö. Brook és Bowler, 1992; Vance és Wells, 1994). Bishop (1989) hívja fel a figyelmet arra, hogy 
mind a rigidnek értelmezett kategóriahatárok, mind az önálló diagnosztikai kategória hiánya ugyanúgy e gyermekek megfelelô fejlesztése ellen hatnak.

A zavar tüneteinek leírása során a kutatók gyakran teljesen eltérô, részben szubjektív, megfigyeléses alapú módszertanokkal is hasonló jelenségekre figyeltek fel (Adams és Bishop, 1989; Bishop és Rosenbloom, 1987; Bishop és Adams, 1989; Gagnon, Mottron és Joanette, 1997; Rapin és Allen, 1983, 1998). Ezekre a gyermekekre jellemzô: az expresszív nyelv oldalán a túlzott bôbeszédúség; a fluens, jól formált megnyilatkozásokból álló beszéd; a magában beszélés; a fejlett szókincs és viszonylag jól strukturált szintaxis; az echolália, gyakran szemantikai parafáziákkal együtt; valamint a zsargonszavak használata. A felszínen látszólag normális nyelvtani fejlôdést mutatnak, de gyakran használnak szokatlan nyelvi konstrukciókat, miközben komplex megértési problémákkal küzdenek (Botting és Conti-Ramsden, 1999). A társalgásokban nehézkes tématartás jellemzi óket; gyakran nem a kérdésre válaszolnak; gyakrabban kezdeményeznek beszélgetést felnôttekkel, de megnyilatkozásuk formailag, szociálisan, tartalmilag vagy stílusban nem a helyzetnek megfelelő; sokat kérdeznek anélkül, hogy észrevennék, hogy már kaptak választ; nehezen értenek meg olyan társalgásokat, ahol a történések nem azonnal következtethetôk ki a fizikai kontextusból; a megnyilatkozásokat hajlamosak szó szerint értelmezni; nem érzékelik a szociális szabályokat; lassan vagy egyáltalán nem értik meg a kontextus összefüggéseit; valamint általában nem érzékelik a prozódia által hordozott jelentéseket.

A 2000-es években kezdtek a kutatók a specifikus, csak ezekre a gyermekekre jellemzô jegyekre mint megkülönböztetô jegyekre fókuszálni. Ekkor indultak a más fejlôdési zavarokkal való célzott összehasonlítások, amelyek végül az önálló diagnosztikai kategória megalkotásához vezettek (pl. Bishop, 2000; Bishop és Norbury, 2002; Botting és Conti-Ramsden, 2003; Barrett, Prior és Manjiviona, 2004; Gibson, Adams, Lockton és Green, 2013; Portway és Johnson, 2003; Reisinger, Cornish és Fombonne, 2011).

\section{A TÁRSAS (PRAGMATIKAI) KOMMUNIKÁCIÓS ZAVAR DEFINÍCIÓJA ÉS DIAGNOSZTIKAI LEHETŐSÉGEI}

A társas pragmatikai kommunikációs zavarral élő gyermekek a kommunikációs helyzetek meg nem értéséból fakadó nehézségekkel küzdenek. E nehézségeiket azonban gyakran jól palástolják: a nem túl bonyolult, begyakorolt, vagy nagymértékben hétköznapi szociális helyzetekre jó stratégiákat építenek ki, így a háttérben fennálló súlyos pragmatikai zavaruk a felületes szemlélő számára nem feltétlenül válik nyilvánvalóvá.

\section{A kurrens definíció elözményei}

A PKZ jelenségének '80-as évekbeli felfedezését az elôzô fejezetben bemutattuk. A DSM-IV-ben (1994) bevezetett pervazív fejlődési zavarok között jelent meg a nem specifikált pervazí fejlödési zavar (pervasive developmental disorder not otherwise specified, PDD-NOS). Az általános megfigyelések szerint ezek a gyermekek azok, akik a mai besorolás szerint a társas pragmatikai kommunikációs zavar kódot kapják. 
A nem meghatározott pervazív fejlôdési zavar terminus már megalkotásakor is jelentôs kritikát kapott amiatt, hogy nem kellôen informatív, alulspecifikált és nem segíti a szakembereket a diagnózisalkotásban. Luteijn és munkatársainak (2000) kritikája szerint a nem meghatározott pervazív fejlôdési zavar leginkább az ICD-10 kategorizációja szerinti atipikus autizmus (F 84.1) csoportjának felel meg. A diagnosztikai kézikönyv (DSM-IV) meghatározása szerint ezek a gyermekek nehézséget mutatnak az autisztikus triász összetevôi közül legfeljebb két területen: a reciprok szociális interakciók fejlôdésében és/vagy a kommunikációban és/vagy a repetitív viselkedésben és korlátozott érdeklôdésben. A megfigyelések szerint a PDD-NOS-os gyermekekre leginkább a szociális interakciókban és a kommunikációban tapasztalható elmaradás, a repetitív viselkedés és korlátozott érdeklôdés általában nem jellemzô. Emellett gyakran jellemzi óket expresszív vagy receptív nyelvi zavar. A PDD-NOS kategóriájának bevezetése után - amely deklarálta e zavarnak az autizmus spektrum zavarral való szoros rokonságát - merült fel a deficit genetikai hátterének vizsgálata. Eszerint az autizmushoz nagyon hasonló genetikai háttér feltételezhető (Towbin, 2005).

A fogalom bevezetése után számos vizsgálat indult a PDD-NOS, az autizmus spektrum zavar és az Asperger-szindrómával diagnosztizált gyermekek összehasonlítására. E három csoportra jellemzô jellegzetességek leírására vállalkoztak Walker és munkatársai (2004). Vizsgálatukban autizmusspecifikus diagnosztikai eszközök segítségével, valamint nyelvi és kognitív tesztekkel mértek fel 270 gyermeket, vizsgálva a kommunikációs és szociális képességeiket, anyanyelv-elsajátításuk szintjét és intelligenciájukat. Elemzésük azt mutatta, hogy a PDD-NOS-os gyermekek eredményei minden vizsgált tényezóben szignifikánsan jobbak voltak az autizmus spektrum zavarral élố gyermekek eredményeinél, de a legtöbb tényezôben nem különböztek szignifikánsan az Asperger-szindrómával élooktôl. Az Asperger-szindrómával élóknél a szerzók szignifikánsan jobb eredményt mértek a kommunikáció és anyanyelv-elsajátítás funkcióiban mind az ASD-s, mind a PDD-NOS-os csoporthoz képest. A PDD-NOS-os gyermekek valamennyi vizsgált funkcióban a két másik csoport között helyezkedtek el az eredmények tekintetében. Mandy, Charman, Gilmour és Skuse (2011) tanulmányukban erôsen problematikusnak tartják, hogy a PDD-NOS-os gyermekeket a csoportra jellemzó diszfunkciók leírása helyett kizárásos alapon definiálják: azok a gyermekek kapják ezt a kódot, akik nem érik el az autizmus spektrum zavar küszöbértékét. A diagnosztikai kritériumok szerint akkor sorolható ebbe a kategóriába egy gyermek, ha az autisztikus triász két tünetcsoportját kimeríti, de a harmadikban nem mutat elmaradást. Megállapításuk szerint ezen gyermekek diagnosztizálásához szükség volna nem autizmusspecifikus vizsgálatok elvégzésére is, hogy az ASD-tôl való különbség minôségi természete is világossá váljon a mennyiségi különbségeken túl. Eredményeik szerint a PDD-NOS-os gyermekek 97\%-a a szociális interakcióban és kommunikációban korlátozott, beszúkült érdeklốdés nem jellemzi ôket (Mandy és mtsai, 2011). Mindez megfelel a PKZ esetében látott jellegzetességeknek.

A DSM-IV és DSM-5 kategóriáinak megfeleléseit több kutatás is vizsgálta (Huerta, Bishop, Duncan, Hus és Lord, 2012; Kim és mtsai, 2014; Kulage, Smaldone és Cohn, 2014; Young és Rodi, 2014). Kim és munkatársai (2014) egy koreai külváros teljes 7-12 éves gyermekpopulációjában végeztek felmérést, tanári és szülői kérdôívvel elōszúrve a gyermekeket. Az elôszúrés során autisztikus jegyeket mutató gyermekekkel 
végeztek további vizsgálatokat, melyek során összehasonlították a DSM-IV és a DSM-5 kritériumrendszerét, valamint a minta alapján megbecsülték az ASD-s és PKZ-s populáció méretét és nemi összetételét. Azt találták, hogy a DSM-IV-ben autizmussal vagy Asperger-szindrómával diagnosztizált gyerekek 99, illetve 92\%-a megfelel a DSM-5 autizmus spektrum zavarban leírt kritériumainak, a PDD-NOS-os gyermekeknek pedig a 62\%-a. A többi gyermek ezekból a csoportokból a PKZ kategóriájába illeszthetô a tüneteik alapján. Huerta és munkatársai (2012) szintén nagy mintán végzett vizsgálatában hasonló eredményre jutott. Megállapításuk szerint a DSM-5 kritériumrendszere érzékenyebb és pontosabb a határterületeken álló gyermekek diagnosztizálásában, valamint alkalmasabb az autizmus spektrumon kívül álló gyermekek megkülönböztetésére, különös tekintettel a nyelvi zavarokra, intellektuális korlátozottságokra, az ADHD-ra és a szorongásos zavarokra.

\section{A társas (pragmatikai) kommunikáció zavarának kurrens definíciója}

A meghatározás szerint a társas pragmatikai kommunikáció zavara a verbális és nonverbális kommunikáció szociális használatának primer deficitje. A DSM-5 a korábbi besorolás szerinti pervazív fejlôdési zavar kategóriájából a kommunikációs zavarok közé sorolta át. A társas pragmatikai kommunikációs zavar diagnosztikai kritériumait mutatja be az 1. táblázat.

A jelenlegi kritériumrendszer szerint tehát nem egyszerú mennyiségi eltérés áll fenn az autizmus spektrum zavarhoz képest - azaz nem annak enyhe formájaként tekint rá -, hanem minôségi különbségnek tartja a fennálló tüneteket.

1. táblázat. A társas pragmatikai kommunikációs zavar diagnosztikai kritériumai (forrás: DSM-5, Nussbaum, 2013)

\begin{tabular}{|c|c|}
\hline $\begin{array}{l}\text { A. Folyama } \\
\text { kommunik }\end{array}$ & $\begin{array}{l}\text { I fennálló nehézségek a társas helyzetekben használt verbális és nonverbális } \\
\text { an }\end{array}$ \\
\hline & $\begin{array}{l}\text { 1. Nehézség a kommunikáció társas szándékú használatában. } \\
\text { 2. Nehézség abban, hogy a kommunikációt a kommunikációs helyzethez, illet- } \\
\text { ve a partnerhez alkalmazkodva módosítani tudja. } \\
\text { 3. Nehézségek a társalgás és a történetmesélés szabályainak követésében. } \\
\text { 4. Megértési nehézségek a nem expliciten kijelentett dolgok (pl. következteté- } \\
\text { sek levonása) és a nem szó szerinti vagy kétértelmú jelentések (pl. szólások, hu- } \\
\text { mor, metaforák, az értelmezés kontextusától függó többszörös jelentés) esetén. }\end{array}$ \\
\hline $\begin{array}{l}\text { B. A nehézség } \\
\text { való részvétel, } \\
\text { vagy ezek bár }\end{array}$ & $\begin{array}{l}\text { gek múködésében korlátozzák a hatékony kommunikáció, a szociális életben } \\
\text {, a társas kapcsolatok, az iskolai vagy foglalkozásbeli teljesítmény valamelyikét } \\
\text { mely kombinációját. }\end{array}$ \\
\hline $\begin{array}{l}\text { C. A tünetek } \\
\text { teljesen nyilvá } \\
\text { korlátozott te }\end{array}$ & $\begin{array}{l}\text { a fejlôdés korai idôszakában jelennek meg (de a zavarok nem feltétlenül válnak } \\
\text { ánvalóvá, amíg a szociális kommunikációs követelmények meg nem haladják a } \\
\text { ljesítôképességét). }\end{array}$ \\
\hline $\begin{array}{l}\text { D. A tünete } \\
\text { strukturálás }\end{array}$ & $\begin{array}{l}\text { nem egy másik egészségügyi vagy neurológiai állapot okozza, sem a szavak } \\
\text { a nyelvtan terén fennálló gyenge képességek, és nem magyarázható jobban } \\
\text { um zavarral, értelmi fogyatékossággal (értelmi fejlődés zavarával), globális } \\
\text { el vagy más mentális zavarral. }\end{array}$ \\
\hline
\end{tabular}




\section{Diagnosztikai módszerek és eszközök}

A zavar diagnózisa a strukturális nyelvi képességek megszilárdulása után, 4-5 éves kor körül állítható fel legkorábban. A szúrés során többféle módszer alkalmazása szükséges (szülôi interjú, nevelôi interjúk, közvetlen és közvetett megfigyelések), valamint összehangolt teammunka (fejlesztôpedagógus, pedagógus, logopédus, pszichológus, gyermekpszichiáter). A nemzetközi gyakorlatban számos szúrô- és diagnosztikai eljárás született a pragmatikai nehézségek felmérésére, itt ezek közül csak azokat soroljuk fel, amelyek célja, hogy a PKZ-t megbízhatóan elkülönítsék az autizmus spektrum zavartól vagy más viselkedési (pl. ADHD) és nyelvi (SLI) zavaroktól.

A PKZ szúrését segítô egyik leghatékonyabb eszköz a Children's Communication Checklist (CCC-2, Bishop, 2003). A szülői kérdôív 4-16 éves kor között alkalmazható, 10 modulban, 70 kérdéssel méri fel a gyermek társas kommunikációs képességeit. Megbízhatóságát számos kutatás igazolta (pl. Botting és Conti-Ramsden, 2003; Botting, 2004; Ketelaars, Cuperus, Van Daal, Jansonius és Verhoeven, 2009; Verté és mtsai, 2006). A tengerentúlon széles körben alkalmazott méróeszköz a Yale in vivo Pragmatic Protocol (Schoen, Simmons, Paul és Volkmar, 2014), amely azonban csak 9 éves kortól használható. Segítségével társalgási helyzetekben mérhetôk a pragmatikai képességek és a tudatosság meglehetôs alapossággal. A különbözô pragmatikai nehézségekkel is együtt járó fejlôdési zavarok differenciálását segíti a 6-18 éves kor között alkalmazható Test of Pragmatic Language mérôeszköz (TOPL, Phelps-Terasaki és Phelps-Gunn, 2007). Erôssége, hogy méri az interakciók során használt problémamegoldó stratégiákat. Noha az autizmus spektrum zavar diagnózisához fejlesztették, célszerú felsorolni itt a Diagnostic Interview for Social and Communication Disorders eszközt is (DISCO, Wing, Leekam, Libby, Gould és Larcombe, 2002). Ez az eljárás alkalmas a gyakran másféle tüneteket mutató lányok és nôk kiszúrésére is. Az ô szúrésük nehézsége több tekintetben mutat hasonlóságot a PKZ-val élook szúrésével: mindkét csoport a felszínen jobban alkalmazkodik bizonyos jól ismert szituációkban. A társas pragmatikai kommunikációs zavarral élô gyermekek iskoláskorban való szúrése másféle módszereket igényel, mint fiatalabb életkorban. A Pragmatic Language Skill Inventory (PLSI, Gilliam és Miller, 2006) iskolai szúrésre alkalmas. A DSM-5 kritériumrendszerét követi az EDUTEA kérdőív (Morales-Hidalgo, Hernandez-Martinez, Voltas és Canals, 2017), amely iskoláskorban méri fel a szociális-kommunikációs képességeket, és teszi lehetôvé a PKZ felismerését. A rövid, 11 elemú kérdôív tanári megfigyelésen alapul, és felméri a gyermek iskolai kommunikációs és szociális interakciós képességeit, valamint viselkedését. A spanyol fejlesztésú kérdốiv angol változatban online is elérhetô, kitölthetô: https://psico.fcep.urv.cat/Q4/EduTEA/. A kérdôív elküldése után a válaszokhoz tartozó kiértékelés is letölthetô.

Magyarországon egyelőre jóval korlátozottabbak a célzott szürés és diagnózis lehetôségei. A hazai gyakorlatban többek között az autizmus spektrum zavar diagnosztikájában alkalmazott ADOS (Autizmus Diagnosztikus Obszervációs Séma) 1-4. modulját, valamint az ADI-R-t (Autizmus Diagnosztikus Interjú) használják a szakemberek nemcsak az autizmus spektrum zavar, de a társas pragmatikai kommunikációs zavar diagnosztikájában is. Szúrésre pedig a Szociális Kommunikációs Kérdôív (SCQ Rutter, Bailey és Lord, 2003) alkalmazható magyar nyelven. Célzottan a PKZ-ra vonatkozó, 
pragmatikai képességeket felmérô, átfogó sztenderd eljárás hazánkban egyelőre sajnos nem áll rendelkezésre (Gál, 2015). Gereben és munkatársai (2012) egy, a pragmatikai nyelvi képességeket is mérô, komplex nyelvfejlődési vizsgálati módszert ajánlanak a pragmatikai nehézségekkel küzdô magyar anyanyelvú gyermekek felmérésére: a Marburger Sprachversändnistest für Kinder tesztjének magyarra fordítva csak kéziratban létezô, így csak korlátozottan elérhetô változata használható (MSVK, Elber és Lohaus, 2000; Sigmund, 2010).

Hazánkban a statisztikák szerint körülbelül százezer ember - vagyis a népesség 1\%-a - él autizmus spektrum zavarral, közülük tizenhatezer gyermek (Csepregi és Stefanik, 2012). Amennyiben a nemzetközi adatok hazánkban is megállják a helyüket, óvatos becslést tehetünk a PKZ-val élôk arányára: a statisztikák szerint a populáció 1\%-a érintett autizmus spektrum zavarban, 0,5\% pedig szociális kommunikációs zavarban. Kim és munkatársainak (2014) Dél-Koreában végzett becslése szerint a populáció 2,2\%-a érintett ASD-ben, és 0,49\%-a PKZ-ben. Ha elfogadjuk e becsléseket, akkor ma Magyarországon mintegy ötvenezer embert, köztük nyolcezer gyermeket érint ez a fejlódési zavar.

A fejlôdési zavar nemi eloszlásáról kevés adat áll rendelkezésre. A témában született vizsgálatok eredményei azt mutatják, hogy az autizmus spektrum zavarban 3-4-szer annyi fiú érintett, mint ahány lány (Csepregi és Stefanik, 2012). A PKZ kutatásában kevés az erre vonatkozó evidencia, a becslés során a nagyobb mintás kutatásokban leírt arányokból következtethetünk: ezek alapján úgy túnik, hogy PKZ-ben kiegyenlítettebb az arány a fiúk és a lányok között. Kim és munkatársai (2014) 1,3 : 1 arányt mértek a fiú : lány összehasonlításban. Az EDUTEA-eljárás eredményeinek elemzése során arra jutottak, hogy a kérdőívben a fiúk magasabb pontszámot értek el, mint a lányok - vagyis kifejezettebb tüneteket mutattak a PKZ-t jellemzô nehézségekben (Morales-Hidalgo és mtsai, 2017).

\section{DIFFERENCIÁLDIAGNÓZIS}

\section{A differenciáldiagnózis nehézségei és irányai}

A legfőbb elméleti kérdés az, hogy a társas pragmatikai kommunikációs zavar az autizmus spektrum zavartól és a specifikus nyelvi zavartól minôségi vagy mennyiségi tényezôk alapján különbözik-e (Botting, 1998). Az önálló diagnosztikai kategória minôségi különbség meglétét sejteti. Norbury (2014b) öt feltételt állapít meg ahhoz, hogy a PKZ megálljon önálló diagnosztikai kategóriaként, ezzel együtt pedig egyértelmúen legyen elkülöníthetô más zavaroktól. Ezek a feltételek a következôk: (1) a klinikai képrôl koherens leírásnak kell születnie; (2) létre kell hozni interkulturálisan is valid sztenderd mérôeszközöket; (3) a különbözô fejlôdési zavarok pragmatikai profilját explicit és mérhetô módon kell összehasonlítani; (4) követni kell a fejlôdési zavar kimenetét, változását az egyénekben; (5) családban végzett felmérésekre van szükség az etiológia megismeréséhez. 
Meglehetôsen kevés olyan kutatást találunk, amely az autizmus spektrum zavar vs. társas pragmatikai kommunikációs zavar vs. specifikus nyelvi zavar hármas differenciáldiagnózisában gondolkodik (ld. Bishop, 2000; Botting és Conti-Ramsden, 2003; Gibson és mtsai, 2013; Simms és Jin, 2015; Taylor és Whitehouse, 2016). Élénk vita van abban a kérdésben is, hogy vajon a más nyelvi és fejlôdési zavarokban is meglévô szociális és kommunikációs nehézségek megbízhatóan elkülöníthetôk-e az önálló fejlôdési zavarként meghatározott PKZ-tól (ld. Swineford és mtsai, 2014).

A differenciáldiagnózist nehezíti még, hogy mind a szociális kommunikációs zavar, mind az autizmus spektrum zavar, mind pedig a pragmatikai nyelvi zavar tünettana változó képet mutat az idô múlásával (Bishop és Norbury, 2002; Geurts és Embrechts, 2008; Lukács és mtsai, 2014). Emellett a nyelvi zavarok és az autizmus spektrum zavar pragmatikai tünetei hasonlóak lehetnek a fejlődés korai szakaszában, de a kognitív fejlôdés elmaradását vagy az érzelemszabályozás atipikus fejlôdését is jelezhetik (Simms és Jin, 2015). Továbbá abban a kontextusban, ahol az SLI és az ASD határterületén álló fejlôdéses zavarnak tekintjük a PKZ-t, szükségszerúen felmerül a kérdés, hogy az SLI és az ASD között lehetséges-e és mekkora átfedés. Kutatások bizonyítják, hogy van az autizmus spektrum zavarnak olyan formája, amelyben nyelvi zavar is jelen van (Conti-Ramsden, Simkin és Botting, 2006; Tager-Flusberg, 2004).

\section{Megkülönböztetése a magasan funkcionáló autizmustól}

Fontos leszögezni, hogy az autizmus spektrum zavarban önmagában is fennáll egy általános szociális, kommunikációs, pragmatikai zavar (ld. pl. Baron-Cohen, 1988). A megkülönböztetés a magasan funkcionáló autista személyekkel való összehasonlításban jelent nehézséget, nem általában az autizmussal. A társas pragmatikai kommunikáció zavarának az autizmus spektrum zavartól való elkülönítésére született vizsgálatok egy része még a DSM-5 eloott készült (Baird és Norbury, 2016; Bishop, 1989, 2000; Bowler és Brook, 1998; Matson és Neal, 2010; Norbury, 2014a; Reisinger és mtsai, 2011; Visser és Tops, 2017). Az eredmények azt mutatják, hogy a magasan funkcionáló autista személyektôl a PKZ-ban érintettek pusztán a nyelvi viselkedéses jegyek alapján nem különböztethetôk meg megbízhatóan. Az autizmusban érintett gyermekek pragmatikai korlátozottságát ugyanis az autizmus tágabb diagnózisában célszerú értelmezni (Swineford és mtsai, 2014). Norbury (2014a) vizsgálatában arra jutott, hogy komplex felmérés segítségével, például az ADOS és az SCQ együttes alkalmazásával a társas pragmatikai kommunikációs zavarban érintett gyermekek megkülönböztethetốk a magasan funkcionáló autista személyektôl. Tanulmányában leszögezi, hogy ezen eljárások pusztán mennyiségi alapon különítik el a két diagnosztikai kategóriát, ami a PKZ pontos megértéséhez nem elegendô. Hasonló módszerrel hasonló eredményre jutnak Reisinger és munkatársai is (2011). Visser és Tops (2017) leíró áttekintésükben a legfóbb problémának azt tartják, hogy míg az autizmus spektrum zavarnak van múködô, kidolgozott diagnosztikai protokollja, addig a PKZ diagnosztikájából ez teljesen hiányzik. Tanulmányuk szerint az ASD-tôl való megkülönböztetés alapja lehet, hogy a PKZ-s gyermekek az autizmussal élôkhöz képest nagyobb nehézségekkel küzdenek a 
strukturális nyelv területén, miközben kevesebb problémájuk van a nonverbális kommunikációval, a repetitív vagy sztereotipikus nyelvi viselkedéssel, és általában beszúkült érdeklődés sem jellemzi óket. Mandy, Wang, Lee és Skuse (2017) nagy mintán végzett elemzésükben (1081 fó) olyan gyermekeket vizsgáltak, akik szociális kommunikációs fejlesztést kaptak. Azt találták, hogy ezek közül a gyerekek közül mindössze 88 rendelkezett PKZ, 801 autizmus spektrum zavar diagnózissal, 192 pedig egyik csoportba sem volt sorolható. Véleményük szerint tehát azoknál a gyermekeknél hasznos a PKZ diagnózis felállítása, akik éppen az ASD küszöbértéke alá esnek, és másképpen nem kapnának fejlesztést.

\section{Megkülönböztetése a specifikus nyelvi zavartól}

A specifikus nyelvi zavar (SNYZ) önmagában is összetett: a tipikus anyanyelvi fejlôdéstôl valamely nyelvi szinte (ke)n vagy funkció(k)ban fennálló nehézségek tartoznak ebbe a kategóriába. A BNO-10 meghatározása szerint: „Olyan zavarok, melyekben a nyelvelsajátítás normál folyamatai már a korai életszakaszban zavart szenvednek.” Az érintett gyermekek tehát elmaradást mutathatnak a nyelv expresszív és/vagy receptív oldalán, bármely nyelvi szinten, miközben intellektusuk ép, és nem áll fenn neurológiai vagy a beszédszerveket érintô nehézség (Lukács és mtsai, 2014). A PKZ kutatásához hasonlóan az SNYZ kutatása során is fontos vitapont, hogy a tipikustól eltérô fejlôdés vajon mennyiségi, vagy ennél mélyebben gyökerezô nehézség, azaz minôségi különbségnek tekinthetô-e. A társas pragmatikai kommunikációs zavartól való elkülönítést az is nehezíti, hogy a nyelv bármely szintjének zavara vezethet szociális és pragmatikai nehézségekhez amiatt, hogy a gyermek a kommunikációs helyzetekben nem konvencionális módon vesz részt (Bishop, 2000). A differenciáldiagnózis során az egyes részképességekben mutatott különbségek segíthetnek a megfelelô diagnózis megtalálásában. Bishop és Adams (1992), valamint Ketelaars, Cuperus, Jansonius és Verhoeven (2010) vizsgálatai szerint a receptív nyelvtani feladatokban az SNYZ-s gyermekek rosszabbul teljesítenek a PKZ-s gyermekekhez képest; emellett azonban a szituációs kontextusból - vagyis nem a verbális jelentéstartalomból - megérthetó következtetések levonásában az SNYZ-s gyermekek teljesítettek jobban a PKZ-s gyermekekhez képest, de mindkét csoport negatívan tér el a tipikus fejlôdésúektôl. Emellett mind társas pragmatikai kommunikációs zavarral, mind pedig specifikus nyelvi zavarral élố gyermekeknél fokozott veszélyt jelent a szociális izoláció és szorongás (Norbury, 2014b). Szem elôtt kell azonban tartani, hogy a specifikus nyelvi zavarban a szociális és pragmatikai nehézség többnyire szekunder tünet, a nyelvi elmaradás következménye.

\section{Átfedések és komorbiditás ADHD-val}

A kutatások szerint a PKZ leggyakrabban a figyelemhiányos hiperaktivitás-zavarral (ADHD) mutat komorbiditást. ADHD-ban a tünetek egyenes következménye a pragmatikai megértésben is mutatott nehézségek (ezek összefoglalását ld. Green és mtsai, 2014). Az ADHD-s gyermekek olyan, a fejlôdési szintjüknek nem megfelelố szociális vi- 
selkedést sajátítanak el, amely megnehezíti a szociális helyzetekhez és normákhoz való alkalmazkodásukat, ezért a kortárs kapcsolataikra gyakran hasonló mintázat jellemzô, mint a PKZ-val, illetve autizmus spektrum zavarral éló társaikra. Luteijn és munkatársai (2000) nagy mintán (545 fô) végzett tanulmányukban ADHD-s és PDD-NOS-os gyermekek szociális problémáit hasonlították össze. A vizsgált gyermekeket négy csoportba sorolták: nem specifikált pervazív fejlôdési zavar; nem specifikált pervazív fejlôdési zavar ADHD-val; „tiszta” ADHD-val élố gyermekek; kontrollcsoportként pedig valamilyen szorongásos zavarral élő gyermekeket vizsgáltak. Emellett magasan funkcionáló autista és tipikus fejlôdésű gyermekeket is bevontak a vizsgálatba. Eredményeik azt mutatták, hogy mind a PDD-NOS-, mind PDD-NOS ADHD-val, mind a „tiszta” ADHD-csoportban súlyos szociális viselkedéses nehézségek álltak fenn, a PDD-NOS-os gyermekek szignifikánsan alacsonyabb eredményt értek el a „tiszta” ADHD-s csoporthoz képest mind a szociális interakciók, mind a kommunikáció, mind a rugalmas viselkedésszervezés területén, de az ADHD-val élô nem specifikált pervazív fejlôdési zavaros csoporttól már nem különböztek szignifikáns mértékben. A „tiszta” ADHD-s csoport és a PDD-NOS ADHD-val csoport között csak a szociális interakciókban mutatkozott szignifikáns különbség: az elôbbi csoport jobb teljesítményt ért el, mint az utóbbi. Eredményeikbôl kiderül ugyanakkor az is, hogy a magasan funkcionáló autista csoport szignifikánsan nagyobb nehézséget mutat az autisztikus triász minden részterületén a PDD-NOS-os csoporthoz képest is. Eredményeikbôl világossá válik, hogy a „tiszta” esetekben a differenciáldiagnózis a megfelelő eszközökkel lehetséges, ám a komorbid esetekben a szakembereknek nincsen könnyú dolguk.

\section{A FEJLÓDÉSI ZAVAR KIMENETE}

Mivel a vizsgált fejlôdési zavar más elnevezéssel ugyan, de 30 éve ismert, ezért rendelkezésre állnak olyan longitudinális vagy felnôttkorban végzett vizsgálatok, amelyekben a kezelt és nem kezelt esetek fiatal- és felnôttkori kimenetelét vizsgálták. A longitudinális vizsgálatok esetében nyilvánvaló nehézséget jelent az évek során többször változó terminológia, valamint a diagnosztikai kategóriák pontos leírásának változása. Ez megnehezíti a vizsgálati személyek eredményeinek értelmezését és értékelését. Mindezen problémák, valamint a témában végzett kutatások eltérô módszertanai ellenére azt látjuk, hogy az eredmények hasonló irányba mutatnak. A prognózis fejlesztés nélkül nem túl jó: negatívan hat a tanulásra, alacsonyabb önbizalommal és nem asszertív kommunikációs formákkal jár együtt, és szociális szorongást okoz (Pickard, Rijsdijk, Happé és Mandy, 2017; Halls, Cooper és Creswell, 2015). Pickard és munkatársainak (2017) nagy mintán végzett longitudinális vizsgálatai azt mutatták, hogy a szociális és kommunikációs nehézségek erôs rizikófaktorai a szociális szorongás kialakulásának: a korán kialakult szociális-kommunikációs nehézségek hozzájárultak a szorongás kialakulásához. Halls és munkatársai (2015) azt találták, hogy a szociális szorongással diagnosztizált gyermekek körében szignifikánsan gyakoribb valamilyen mértékú szociális-kommunikációs zavar, mint más szorongásos kórképekkel kezelt gyermekeknél. Megfeleló intervenció nélkül a tünetek kamaszkorban és fiatal felnôttkorban súlyosbodhatnak (Simms és Jin, 2015). Kamaszkorban a furcsa viselkedésük miatt kortársaik 
elhúzódhatnak tôlük, felnôttkorban pedig a munkavállalásra hathat negatívan a nem kezelt állapot (Towbin, 2005). Helland és munkatársainak (2014) ötéves utánkövetéses vizsgálata azt mutatja, hogy a pragmatikai nyelvi zavarban érintett gyermekeknél az inadekvát kommunikáció következményeként fellépô problémák az állandó stressz-szint növekedéséhez, elmagányosodáshoz, kényszeres viselkedéshez és mentális problémákhoz vezethetnek. Ketelaars és munkatársai (2010) erôs korrelációt fedeztek fel a pragmatikai nehézségek és a kortársproblémák között: kutatásuk szerint a pragmatikai képességekben mutatkozó nehézségek kiváló prediktorai számos viselkedési problémának, míg a receptív nyelvtani képességekben mutatkozó nehézségek nem korrelálnak a viselkedési problémákkal. A leghosszabb követéses periódust Mordre és munkatársainak (2012) kutatásában találjuk, ók 30 éven keresztül végeztek felméréseket összesen 113 autizmus spektrum zavarral és nem specifikált pervazív fejlôdési zavarral élô személlyel. Eredményeik azt mutatják, hogy a két csoportban átlagosan $83 \%$ a rokkantnyugdíjra jogosultak száma, 95\%-uk pedig nem élt házasságban. Hofvander és munkatársai (2009) autizmus spektrum zavarral, Asperger-szindrómával, valamint nem specifikált pervazív fejlôdési zavarral élô felnôttek pszichoszociális nehézségeit vizsgálták. Eredményeik között viszonylag magas iskolázottságot találtak mindhárom csoportban, a vizsgálati személyek 65\%-a érettségivel, 24\%-a diplomával rendelkezett. Azonban mindössze 43\%-uk tudott elhelyezkedni a munkaerőpiacon, 84\%-uk pedig soha nem létesített hosszú távú párkapcsolatot. Whitehouse, Line, Watt és Bishop (2009) olyan felnôtteket vizsgáltak, akik autizmus spektrum zavar, specifikus nyelvi zavar vagy PKZ diagnózist kaptak gyermekkorban. A társas pragmatikai kommunikációs zavarral élốk magasabb szintú végzettséggel rendelkeztek a két másik csoporthoz képest, és alapos szaktudást igénylő munkakörökben is el tudtak helyezkedni.

A hazai gyógypedagógiai tapasztalatok azt mutatják, hogy idóben indított, komplex, szociális-kommunikációs intervencióval, folyamatos támogatás mellett az érintett gyermekek általában integráltan nevelhetôk. ${ }^{3}$

\section{ÖSSZEGZÉS}

A PKZ tünettanának, etiológiájának és kimenetének feltárása, valamint a megfelelô diagnosztikai és intervenciós módszertan(ok) megalkotása a fejlốdési zavar harminc évvel ezelốtti leírásakor megkezdôdött, de korántsem fejezôdött be. Nemzetközi szinten is kevesen foglalkoznak a témával, hazánkban pedig alig találunk célzott vizsgálatokat. A PKZ jellegzetességeinek, hátterének, kimenetének minél pontosabb megértéséhez, a szúréshez és differenciáldiagnózishoz nélkülözhetetlen volna az egységes módszertan kialakítása. A hazai gyógypedagógiai és diagnosztikus gyakorlatban nagy szükség lenne széles körben elterjedt, magyar nyelven sztenderdizált, a szakemberek számára könnyen hozzáférhetô eszközökre és módszerekre, melyek célzottan a PKZ szúrését és diagnosztikáját segítenék.

3 Jelen tanulmány kereteit meghaladja az intervenciós lehetôségek bemutatása, amely rendkívül fontos téma, ezért önálló dolgozat tárgya kell hogy legyen. 


\section{IRODALOM}

Adams, C., \& Bishop, D. V. M. (1989). Conversational characteristics of children with semantic-pragmatic disorder. I: Exchange structure, turntaking, repairs and cohesion. International Journal of Language E Communication Disorders, 24(3), 211-239.

Baird, G., \& Norbury, C. F. (2016). Social (pragmatic) communication disorders and autism spectrum disorder. Archives of Disease in Childhood, 101(8), 745-751.

Bara, B. G., Bosco, F. M., \& Bucciarelli, M. (1999). Developmental pragmatics in normal and abnormal children. Brain and Language, 68(3), 507-528.

Baron-Cohen, S. (1998). Social and pragmatic deficits in autism: Cognitive or affective. Journal of Autism and Developmental Disorders, 18(3), 379-402.

Barrett, S., Prior, M. \& Manjiviona, J. (2004). Children on the borderlands of autism: Differential characteristics in social, imaginative, communicative and repetitive behaviour domains. Autism, 8(1), 61-87.

Bishop, D., \& Rosenbloom, L. (1987). Classification of childhood language disorders. Language Developmental Disorder, 22, 61-81.

Bishop, D. V. M. (1989). Autism, Asperger's Syndrome and Semantic-Pragmatic Disorder: Where Are the Boundaries? British Journal of Disorders of Communication, 24(2), 107-121.

Bishop, D. V. M. (2000). Pragmatic language impairment: A correlate of SLI, a distinct subgroup, or a part of the autistic continuum? In D. V. M. Bishop, \& L. B. Leonard (Eds), Speech and langauge impairments in children: Causes, characteristics, intervention and outcome (pp. 99-113). Psychology Press, Taylor and Francis Group.

Bishop, D. V. M. (2003). Children's Communication Checklist (CCC-2). Pearson.

Bishop, D. V. M., \& Adams, C. (1989). Conversational characteristics of children with semantic-pragmatic disorder. II: What features lead to a judgement of inappropriacy? The British Journal of Disorders of Communication, 24(3), 241-263.

Bishop, D. V. M., \& Norbury, C. F. (2002). Exploring the borderlands of autistic disorder and specific language impairment: A study using standardised diagnostic instruments. Journal of Child Psychology and Psychiatry, 43(7), 917-929.

Botting, N. (1998). Semantic-pragmatic disorder as a distinct diagnostic entity: Making sense of the boundaries. International Journal of Language and Communication Disorders, 33(1), $71-108$.

Botting, N. (2004). Children's Communication Checklist (CCC) scores in 11-year-old children with communication impairments. International Journal of Language and Communication Disorders, 39(2), 215-227.

Botting, N., \& Conti-Ramsden, G. (1999). Pragmatic language impairment without autism. The children in question. Autism, 3(4), 371-396.

Botting, N., \& Conti-Ramsden, G. (2003). Autism, primary pragmatic difficulties, and specific language impairment: can we distinguish them using psycholinguistic markers? Developmental Medicine and Child Neurology, 45(8), 515-524.

Bowler, D., \& Brook, S. L. (1998). SPD and autistic spectrum disorder. International Journal of Language and Communication Disorders, 33(1), 91-94.

Brook, S. L., \& Bowler, D. (1992). Autism by another name? Semantic and pragmatic impairments in children. Journal of Autism and Developemntal Disorders, 22(1), 61-81.

Conti-Ramsden, G., Simkin, Z., \& Botting, N. (2006). The prevalence of autistic spectrum disorders in adolescents with a history of specific language impairment (SLI). Journal of Child Psychology and Psychiatry, 47(6), 621-628.

Cummings, L. (2014). Pragmatic disorders. Journal of Pragmatics, 80, 86-88. 
Csepregi, A., \& Stefanik, K. (2012). Autizmus spektrum-zavarral élő gyermekek, tanulók komplex vizsgálatának diagnosztikus protokollja. Budapest: Education Társadalmi Szolgáltató és Nonprofit Kft.

Elber, C. E., \& Lohaus, A. (2000). Marburger Sprachvertändnistest für Kinder. (MSVK) Göttingen: Verlag für Psychologie.

Gagnon, L., Mottron, L., \& Joanette, Y. (1997). Questionning the validity of the semantic-pragmatic syndrome diagnosis. Autism, 1(1), 37-55.

Gál, Z. (2015). A szociális kommunikációs képesség méröeszközének fejlesztése 10-19 évesek körében. Budapest: Oktatási Hivatal.

Gereben, F., Fehérné Kovács, Zs., Kas, B. \& Mészáros, A. (2012). Beszéd és nyelvi zavart mutató (beszédfogyatékos) gyermekek, tanulók komplex vizsgálatának diagnosztikus protokollja. Budapest: Educatio.

Geurts, H. M., \& Embrechts, M. (2008). Language profiles in ASD, SLI and ADHD. Journal of Autism and Developmental Disorders, 38(10), 1931-1943.

Gibson, J., Adams, C., Lockton, E. \& Green, J. (2013). Social communication disorder outside autism? A diagnostic classification approach to delineating pragmatic language impairment, high functioning autism and specific language impairment. Journal of Child Psychology and Psychiatry, 54(11), 1186-1197.

Gilliam, J., \& Miller, L. (2006). Pragmatic langauge skills inventory. Austin: PRO-ED Inc.

Green, B., Johnson, K. A. \& Bretherton, L. (2014). Pragmatic language difficulties in children with hyperactivity and attention problems: An integrated review. International Journal of Language and Communication Disorders, 49(1), 15-29.

Gyôri, M. (2014). A nyelv, a kommunikáció és a megismerés atipikus mintázatai és kapcsolatai autizmus spektrum zavarokban. In Pléh Cs. \& Lukács Á. (szerk.), Pszicholingvisztika 2. (pp. 1345-1382). Budapest: Akadémiai Kiadó.

Halls, G., Cooper, P. J. \& Creswell, C. (2015). Social communication deficits: specific associations with Social Anxiety Disorder. Journal of Affective Disorders, 172, 38-42.

Helland, W., Lundervold, A., Heimann, M. \& Posserud, M. B. (2014). Stable associations between behavioral problems and language impairments across childhood. The importance of pragmatic language problems. Research in Developmental Disabilities, 35(5), 943-951.

Hofvander, B., Delorme, R., Chaste, P., Nydén, A., Wentz, E., Stahlberg, O., et al. (2009). Psychiatric and psychosocial problems in adults with normal-intelligence autism spectrum disorders. BMC Psychiatry, 9(35).

Huerta, M., Bishop, S. L., Duncan, A., Hus, V. \& Lord, C. (2012). Application of DSM-5 criteria for autism spectrum disorder to three samples of children with DSM-IV diagnoses of pervasive developmental disorders. American Journal of Psychiatry, 169(10), 1056-1064.

Ketelaars, M. P., Cuperus, J. M., Van Daal, J., Jansonius, K. \& Verhoeven, L. (2009). Screening for pragmatic language impairment: The potential of the children's communication checklist. Research in Developmental Disabilities, 30(5), 952-960.

Ketelaars, M. P., Cuperus, J., Jansonius, K. \& Verhoeven, L. (2010). Pragmatic language impairment and associated behavioural problems. International Journal of Language and Communication Disorders, 45(2), 204-214.

Kim, Y. S., Fombonne, E., Koh, Y. J., Kim, S. J., Cheon, K. A. \& Leventhal, B. L. (2014). A comparison of DSM-IV pervasive developmental disorder and DSM-5 autism spectrum disorder prevalence in an epidemiologic sample. Journal of the American Academy of Child and Adolescent Psychiatry, 53(5), 500-508.

Kulage, K. M., Smaldone, A. M., \& Cohn, E. G. (2014). How will DSM-5 affect autism diagnosis? A systematic literature review and meta-analysis. Journal of Autism and Developmental Disorders, 44(8), 1918-1932. 
Lukács, Á., Kas, B. \& Pléh, Cs. (2014). A specifikus nyelvfejlôdési zavar. In Pléh Cs. \& Lukács Á. (szerk.), Pszicholingvisztika (pp. 1265-1324). Budapest: Akadémiai Kiadó.

Luteijn, E. F., Serra, M., Jackson, S., Steenhuis, M. P., Althaus, M., Volkmar, F. \& Minderaa, R. (2000). How unspecified are disorders of children with a pervasive developmental disorder not otherwise specified? European Child and Adolescent Psychiatry, 9(3), 168-179.

Mandy, W., Charman, T., Gilmour, J., \& Skuse, D. H. (2011). Towards specifying pervasive developmental disorder not otherwise specified. Autism Research, 44, 1-35.

Mandy, W., Wang, A., Lee, I., \& Skuse, D. (2017). Evaluating social (pragmatic) communication disorder. Journal of Child Psychology and Psychiatry and Allied Disciplines, 58(10), 1166-1175.

Matson, J. L., \& Neal, D. (2010). Differentiating communication disorders and autism in children. Research in Autism Spectrum Disorders, 4, 626-632.

Morales-Hidalgo, P., Hernandez-Martinez, C., Voltas, N. \& Canals, J. (2017). A DSM-5 teacher screening questionnaire for autism spectrum disorder and social pragmatic communication disorder. International Journal of Clinical and Health Psychology, 17, 269-281.

Mordre, M., Groholt, B., Knudsen, A. K., Sponheim, E., Mykletun, A., \& Myhre, A. M. (2012). Is long-term prognosis for pervasive developmental disorder not otherwise specified different from prognosis for autistic disorder? Findings from a 30-year follow-up study. Journal of Autism and Developmental Disorders, 42(6), 920-928.

Norbury, C. F. (2014a). Practicioner Review: Social (pragmatic) communication disorder conceptualization, evidence and clinical implications. The Journal of Child Psychology and Psychiatry, 55(3), 204-216.

Norbury, C. F. (2014b). Atypical pragmatic development. In Matthews, D. (Ed), Pragmatic Development in First Language Acquisition (pp. 343-362), Amsterdam: John Benjamins.

Nussbaum, A. M. (2013). A DSM-5 diagnosztikai vizsgálat zsebkönyve. Oriold és Tsai Kft.

Phelps-Terasaki, D., \& Phelps-Gunn, T. (1992). Test of Pragmatic Language. Second Edition (TOPL-2). WPS.

Pickard, H., Rijsdijk, F., Happé, F. \& Mandy, W. (2017). Are social and communication difficulties a risk factor for the development of social anxiety? Journal of the American Academy of Child and Adolescent Psychiatry, 56(4), 344-351.

Portway, S., \& Johnson, B. (2003). Asperger Syndrome and the children who don't quite fit. Early Child Development and Care, 173(4), 435-443.

Rapin, I., \& Allen, D. (1983). Developmental language disorders: Nosological consideration. In Kirk, U. (Ed), Neuropsychology of language, reading and spelling (pp. 155-184). New York: Academic Press.

Rapin, I., \& Allen, D. (1998). The semantic-pragmatic deficit disorder: Classification issues. International Journal of Language and Communication Disorders, 33(1), 71-108.

Reisinger, L. M., Cornish, K. M., \& Fombonne, E. (2011). Diagnostic differentiation of autism spectrum disorders and pragmatic language impairment. Journal of Autism and Developmental Disorders, 41(12), 1694-1704.

Rutter, M., Bailey, A., \& Lord, C. (2003). The Social Communication Questionnaire. Manual. Los Angeles: Western Psychological Services.

Schoen, E., Simmons, R., Paul, R. \& Volkmar, F. (2014). Assessing pragmatic language in autism spectrum disorder: The Yale in vivo Pragmatic Protocol. Journal of Speech, Language and Hearing Research, 57(6), 2162-2173.

Sigmund, Á. (2010). A beszédmegértés vizsgálatának egy újabb módszere: a Marburger Sprachversändnistest für Kinder bemutatása. Szakdolgozat. Budapest: ELTE BGGyK, Pszichológiai Intézet.

Simms, M. D., \& Jin, X. M. (2015). Autism, language disorder, and social (pragmatic) communication disorder: DSM-V and differential diagnoses. Pediatrics in Review, 36(8), 355-363. 
Swineford, L. B., Thurm, A., Baird, G., Wetherby, A. M. \& Swedo, S. (2014). Social (pragmatic) communication disorder: a research review of this new DSM-5 diagnostic category. Journal of Neurodevelopmental Disorders, 6(1), 41.

Taylor, L., \& Whitehouse, A. (2016). Autism spectrum disorder, language disorder, and social (pragmatic) communication disorder: overlaps, distinguishing features, and clinical implications. Australian Psychologist, 51(4), 287-295.

Tager-Flusberg, H. (2004). Do autism and specific language impairment represent overlapping language disorders? In M. L. Rice, \& S. Warren (Eds), Developmental Language Disorders: From Phenotypes to Etiologies (pp. 31-52). Mahvah/New Jersey: Lawrence Erlbaum.

Topal, Z., Samurcu, N. D., Taskira, S., Tufan, A. E. \& Semerci, B. (2018). Social communication disorder: A narrative review on current insights. Neuropsychiatric Disease and Treatment, 14, 2039-2046.

Towbin, K. E. (2005). Pervasive developmental disorder not otherwise specified. In F. R. Volkmar, R. Paul, A. Klin, \& D. Cohen (Eds), Handbook of autism and pervasive developmental disorders (pp. 165-200). Hoboken, NJ: John Wiley.

Vance, M., \& Wells, B. (1994). The wrong end of the stick: language impaired children's understanding of non-literal language. Child Language Teaching and Therapy, 10(1), 23-46.

Verté, S., Geurts, H., Roeyers, H., Rosseel, Y., Oosterlaan, J. \& Segreant, J. A. (2006). Can the Children's Communication Checklist differentiate autism spectrum subtypes? Autism, 10(3), 266-287.

Visser, S., \& Tops, W. (2017). Social pragmatic communication disorder and autism spectrum disorder: Two of a kind? A narrative review. Annual Psychiatry Mental Health, 5(6), 1121.

Walker, D., Thompson, A., Zwaigenbaum, L., Goldberg, J., Bryson, S. E., Mahoney, W. J. et al. (2004). Specifying PDD-NOS: A comparison of PDD-NOS, Asperger syndrome, and autism. Journal of the American Academy of Child and Adolescent Psychiatry, 43(2), 172-180.

Whitehouse, A., Line, E., Watt, H. \& Bishop, D. V. M. (2009). Qualitative aspects of developmental language impairment relate to language and literacy outcome in adulthood. International Journal of Language and Communication Disorders, 44(4), 489-510.

Wing, L., Leekam, S. R., Libby, S. J., Gould, J., \& Larcombe, M. (2002). Diagnostic Interview for Social and Communication Disorders: background, inter-rater reliability and clinical use. Journal of Child Psychology and Psychiatry, 43(3), 307-325.

Young, R., \& Rodi, M. (2014). Redefining autism spectrum disorder using DSM-5: The implications of the proposed DSM-5 criteria for autism spectrum disorder. Journal of Autism and Developmental Disorders, 44(4), 758-765. 


\section{THE SOCIAL (PRAGMATIC) COMMUNICATION DISORDER: TERMINOLOGY, DIAGNOSTIC METHODS AND PROBLEMS}

\section{SVINDT, VERONIKA}

The social (pragmatic) communication disorder (SPCD) is a developmental disorder on the borderland of the autistic spectrum disorder and specific language impairment. Its main symptom is inadequate use of the language in context in spite of relatively intact cognitive abilities. SPCD is a new diagnostic category created in 2013, but it was first described in the 1980's. There has been a thirty-year debate about the strict boundaries of SPCD, its etiology, and its connection to other developmental disorders. Specific formal assessments and rating scales for SPCD are lacking in Hungarian diagnostic protocol and intervention, and the diagnostic category is not well known. The aim of this study is to give an overview of international methods, practice and differential diagnosis.

Keywords: social (pragmatic) communication disorder, pragmatic langauge impairment, autism spectrum disorder, specific language impairment

A cikk a Creative Commons Attribution 4.0 International License (https://creativecommons. org/licenses/by/4.0) feltételei szerint publikált Open Access közlemény, melynek szellemében a cikk bármilyen médiumban szabadon felhasználható, megosztható és újraközölhetô, feltéve, hogy az eredeti szerzô és a közlés helye, illetve a CC License linkje és az esetlegesen végrehajtott módosítások feltüntetésre kerülnek. (SID_1) 